\title{
Adaptation of Ranaviruses from Peneda-Gerês National Park (Portugal) to Cell Cultures and their Characterization
}

\author{
Alves de Matos A.P.*, Caeiro M.F.**, Marschang R.E.***, Papp T.***, Soares C.****, Marçal \\ M.R.***** and Carretero M.A.**** \\ *Dental Medical School, University of Lisbon 1649-003 Lisbon and Curry Cabral Hospital, 1069- \\ 166 Lisbon, Portugal. \\ **University of Lisbon, Faculty of Sciences, Dept. of Plant Biology and Environmental Biology \\ Centre, Lisbon, Portugal. \\ ***Institut für Umwelt- und Tierhygiene, Hohenheim University, Garbenstr. 30, 70599 Stuttgart, \\ Germany. \\ ****CIBIO, Centro de Investigação em Biodiversidade e Recursos Genéticos; 4485-661 Vairão; \\ Portugal. \\ $* * * * *$ National Laboratory for Veterinary Investigation, Lisbon, Portugal.
}

Ranaviruses are known to produce diseases in fish, amphibians and reptiles, being involved in high mortality episodes in aquaculture farms and in the decline of amphibian populations worldwide [1]. Mass mortality episodes were previously detected in Triturus marmoratus from two lagoons of the Peneda-Gerês National Park (PGNP) (NW Portugal) [2]. Ranavirus-like particles were identified in tissues of diseased newts T. marmoratus and T. boscai [3]. Here we report on the molecular and ultrastructural characterization of these viruses.

Samples of infected T. marmoratus and T. boskai from the Carris lagoon of the PGNP were used to infect IgH-2 and Vero cell lines. Infected cultures were monitored by transmission electron microscopy at several hours post infection. The viruses were further characterized by PCR with primers for a conserved region of the major capsid protein of members of the Ranavirus genus of the Iridoviridae family [4]. Proteins extracted from infected Vero cells labelled with 35S methionine and cysteine were analyzed by SDS-PAGE.

Cytopatic effects were observed in cells from the 5th passage onwards. The viruses adapted to the cell cultures were ultrastructurally similar to the viruses found in the tissues of the diseased animals (Figs 1 to 2), and the ultrastructural features of the morphogenesis were consistent with those known on the morphogenesis of ranaviruses (Figs 2-3). Also, the PCR reaction for detection of ranaviruses gave positive results (Fig. 4), and the polypeptide profiles showed a pattern resembling the FV3 type species showing the characteristic 50K major capsid protein band (Fig. 5).

Our results demonstrate that the viruses inducing disease in the amphibians of the PGNP are typical ranaviruses. Further work is needed to compare these viruses to other ranavirus isolates in order to evaluate their affinities.

\section{References}

[1] Williams, T. et al., Adv. Virus Res. 65 (2005)173-248.

[2] Soares, C. et al., Froglog 56 (2003) 1.

[3] Alves de Matos, A. P. et al., Symposium on the declining of the populations of amphibans. 
Societat Catalana d'Herpetologia-Universitat de Lleida., Lleida, (2004) pp 39-42.

[4] Marschang R. E. et al., Arch Virol 144 (1999) 1909-1922

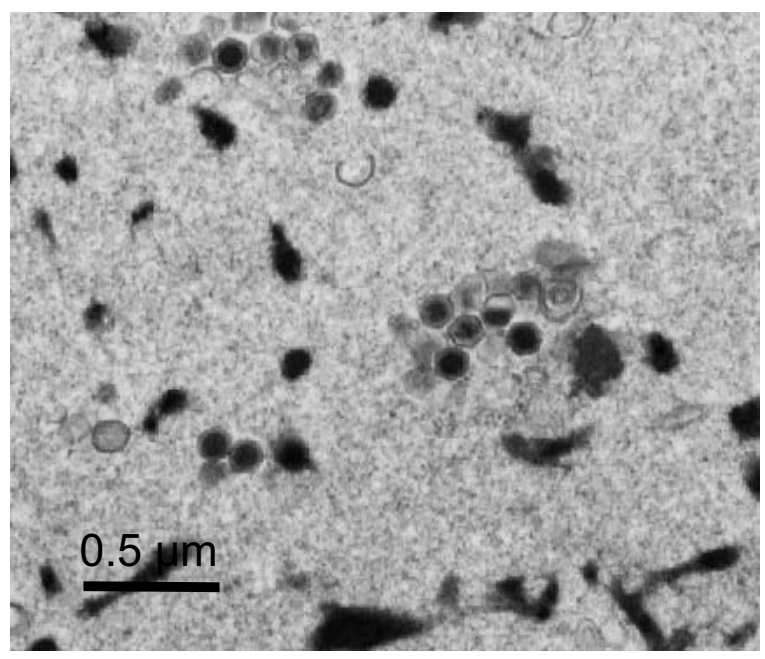

Fig.1 Viruses found in the diseased $T$. marmoratus subcutaneous tissue.

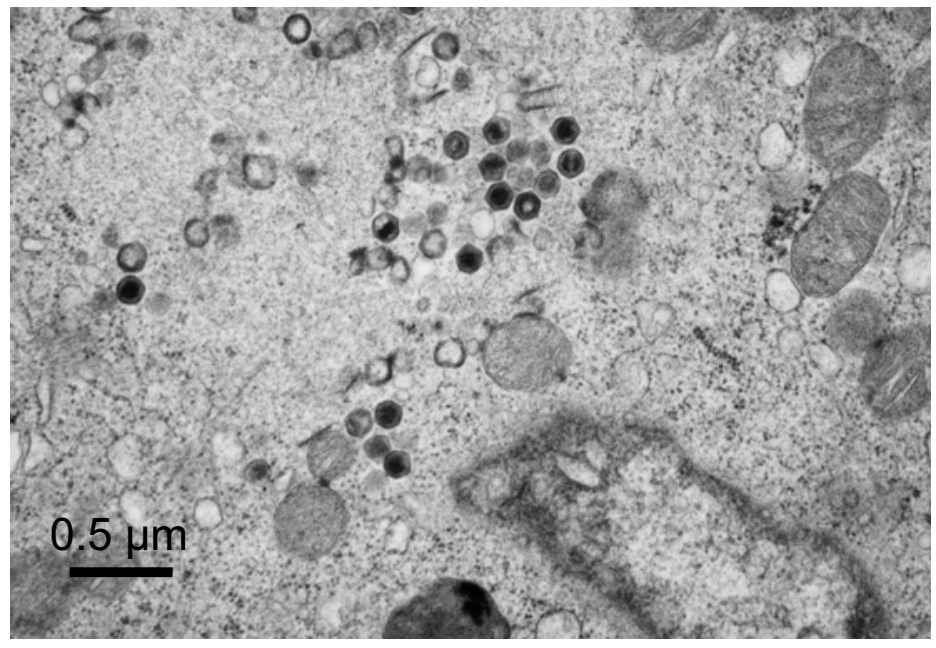

Fig. 2 - T. marmoratus virus adapted to Vero cells.

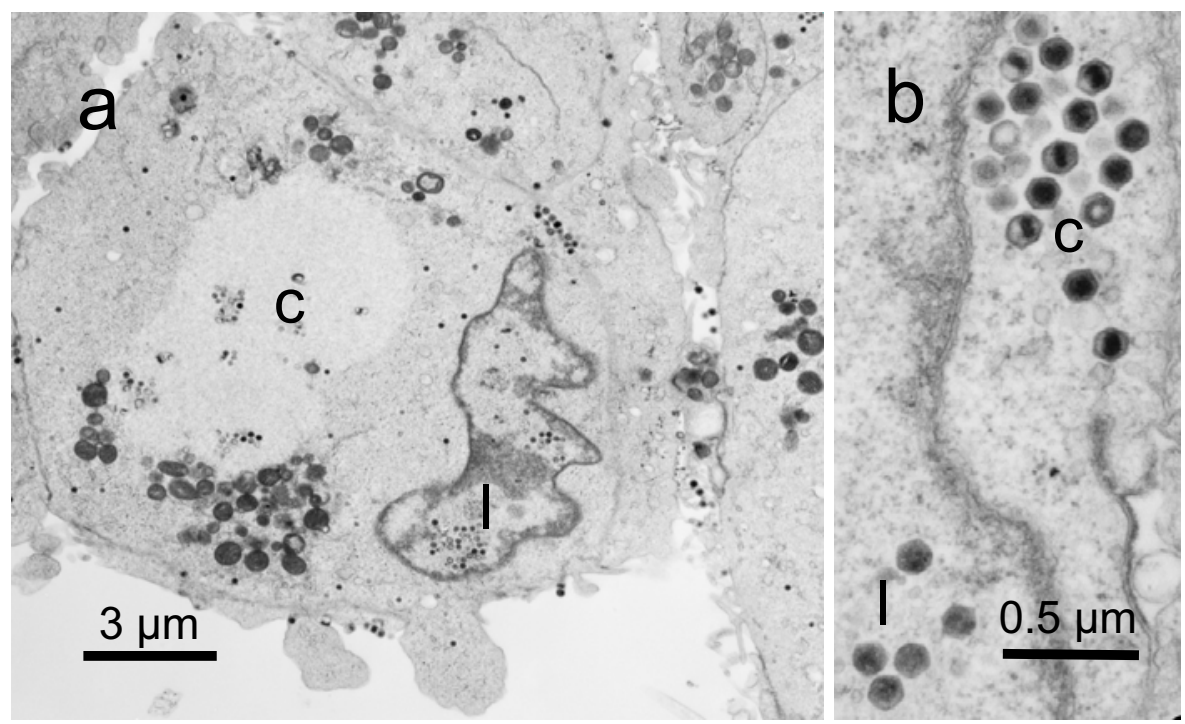

Fig. 3 - (a) T. boskai virus adapted to Vero cells. (b) Intranuclear virions. C - Cytoplasmic viruses; I - Intranuclear viruses.
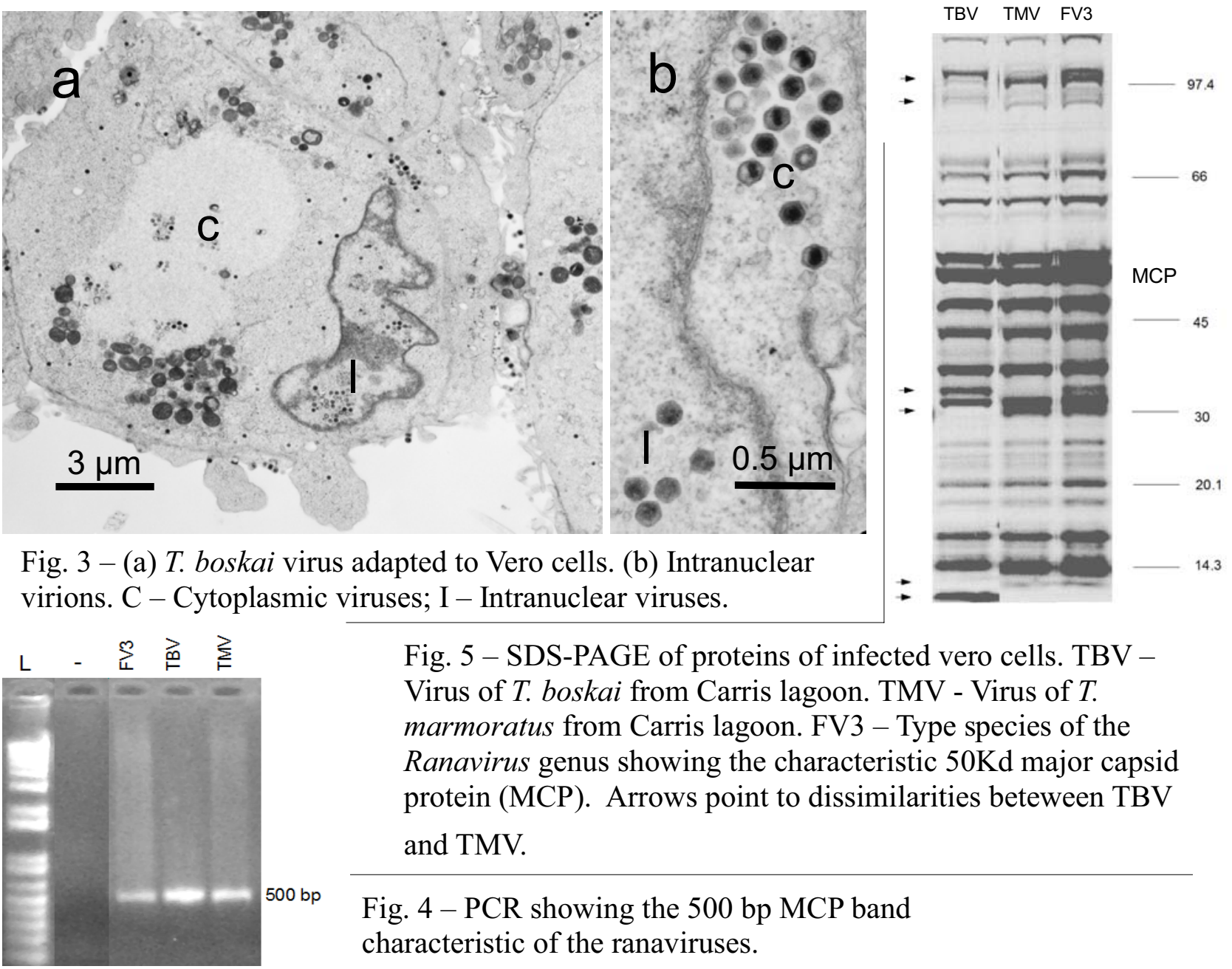

Fig. 5 - SDS-PAGE of proteins of infected vero cells. TBV Virus of T. boskai from Carris lagoon. TMV - Virus of $T$. marmoratus from Carris lagoon. FV3 - Type species of the Ranavirus genus showing the characteristic 50Kd major capsid protein (MCP). Arrows point to dissimilarities beteween TBV and TMV.

Fig. 4 - PCR showing the 500 bp MCP band characteristic of the ranaviruses. 